\title{
Commentary
}

\section{Mimicking microbial 'education' of the immune system: a strategy to revert the epidemic trend of atopy and allergic asthma? \\ Paolo Maria Matricardi ${ }^{\star \dagger}$ and Sergio Bonini ${ }^{\dagger}$ \\ *DASRS, Pomezia (Rome), and 'Institute of Experimental Medicine, CNR, Rome, Italy}

\begin{abstract}
Deficient microbial stimulation of the immune system, caused by hygiene, may underly the atopy and allergic asthma epidemic we are currently experiencing. Consistent with this 'hygiene hypothesis', research on immunotherapy of allergic diseases also centres on bacteria-derived molecules (eg DNA immunostimulatory sequences) as adjuvants for allergen-specific type 1 immune responses. If we understood how certain microbes physiologically 'educate' our immune system to interact safely with environmental nonmicrobial antigens, we might be able to learn to mimic their beneficial actions. Programmed 'immunoeducation' would consist of safe administration, by the correct route, dose and timing, of those microbial stimuli that are necessary to 'train' the developing mucosal immune system and to maintain an appropriate homeostatic equilibrium between its components. Overall, this would result in a prevention of atopy that is not limited to certain specific allergens. Although such a strategy is far beyond our present potential, it may in principle revert the epidemic trend of atopy and allergic asthma without jeopardizing the fight against infectious diseases.
\end{abstract}

Keywords: allergy, asthma, DNA immunostimulatory sequences, epidemiology, lactobacilli, lipopolysaccharide, mycobacteria, prevention, therapy

\section{Introduction}

Allergic asthma is on the increase in Western countries, as are efforts to identify the reasons for this increase [1]. This trend is part of a generalized increase in prevalence of atopic conditions that are characterized by mucosal eosinophilic inflammation, such as allergic rhinoconjunctivitis and atopic eczema [1,2]. The allergy 'epidemic' appears to parallel the overly hygienic conditions that are typical of affluent societies [3-5]. Hence, the hygiene hypothesis has been suggested. According to this hypothesis, changing interactions between humans and microbes of their ecosystem alter the immune balance at mucosal level between type 1 (Th1, Tcl) and type 2 (Th2, Tc2) immunity, thereby predisposing to atopic diseases $[5,6]$, including allergic asthma. Partially deprived of appropriate microbial stimulation, type 1 immune mechanisms would no longer downregulate the hypersensitivityand allergy-causing type 2 response to a sufficient degree $[1,5-11]$.

Although the hygiene hypothesis remains a hypothesis, it raises questions. Must we go back to living in 'dirty' 
conditions? Are allergy and asthma an unavoidable price that westernized societies must pay for the decline in morbidity and mortality from infectious diseases?

\section{Will 'poor' hygiene cure asthma?}

The answer to this provocative question is 'no'. Many respiratory infections induce wheezing, and many cases of wheezing that are linked to recurrent respiratory infections are labelled 'asthma' or are perceived as such [12]. Some respiratory viruses (eg respiratory syncytial virus) induce asthma in predisposed individuals [13], whereas others (eg rhinoviruses) exacerbate pre-existing atopic bronchial inflammation [14].

The rising trend in severe asthma cases in poor, and hence supposedly less hygienic, urban areas of US cities ('inner city asthma') appears to refute the hygiene hypothesis [15]. Therefore, the words 'dirty' or 'hygiene' are too generic to be used to label environments that facilitate or protect against allergy. We must still learn whether and what kind of hygienic measures cause atopy, and generic antihygienic procedures would obviously facilitate the spread of infectious diseases.

By contrast, the traditional lifestyle that is typical of anthroposophic [16] and farming communities [17] appears highly protective, given the very low prevalence of respiratory allergies in these groups. However, it remains to be established whether the lower prevalence of atopy is due to higher exposure to microbes or to other hallmarks of a rural lifestyle [18]. Less indirect support for the hygiene hypothesis came from epidemiological studies of Italian military cadets $[19,20]$, which showed that exposure to food-borne and orofaecal infections, but not to air-borne viruses, was inversely associated with respiratory allergies. These serological studies support the notion that a high turnover of ingested microbes (mainly saprophytic, commensal and pathogen bacteria) at mucosal surfaces, in particular the gut mucosa, may 'educate' our mucosal immune system to interact safely with nonmicrobial antigens [21-24]. This would explain why the children of farmers and anthroposophic communities are protected against bronchial allergy and other atopic diseases $[16,17,22,25]$. Interestingly, the concentration of exogenous lipopolysaccharide in house dust was inversely related to atopy among infants at risk for asthma [26]. This suggests that not only ingested bacteria, but also bacterial immunostimulating substances from inhalable sources could also afford protection against allergy.

Given these premises, we may ask if children living in US inner cities are exposed to a sufficiently diversified set of bacteria and if they eat sufficiently contaminated food. It would be interesting to determine the magnitude of exposure to orofaecal and food-borne infections [22], and to saprophytic bacteria-contaminated soil [11], in inner cities. It is tempting to speculate that allergic children living in those 'unhygienic' areas inhale and ingest a different kind, variety and amount of bacteria compared with children of farmers and anthroposophic families, who have access to natural soil and eat only biologically treated food (fresh vegetables and farm products).

\section{Bacteria and bacterial substances that may prevent atopy}

To exert an atopy-preventing effect, it is thought microbes must be present where and when allergen uptake, processing and presentation to T cells occur $[9,10]$. Appropriate bacteria would act as natural Th1 'adjuvants' during the priming of $T$ cells against newly encountered environmental antigens. Facultative and professional antigen-presenting cells (dendritic cells) may be the target of a microbial bystander effect, that may dictate the pattern of accessory molecules and cytokines, and modulate the outcome (Th1- or Th2-like) of the allergen-specific T-cell response $[9,27]$.

At least five kinds of bacteria or bacterial substances are being examined for their proven or alleged atopy-preventing effect, and these are discussed below.

\section{Immunostimulatory sequences}

Short immunostimulatory DNA sequences with CpG motifs are 20 times as frequent in bacterial DNA as in mammalian DNA [28]. Immunostimulatory sequences are among the strongest of the known Th1-stimulating adjuvants; they suppress $\lg \mathrm{E}$ responses and eosinophilic recruitment in vivo, and prevent allergic asthma in animal models [29]. Adjuvant DNA immunostimulatory sequences can provide part of the immunostimulatory effects of Freund's adjuvant without the severe inflammatory and toxic side effects attributed to the paraffin oil and mycobacterial cell wall products [30].

\section{Mycobacterium vaccae}

An inverse association between atopy and reactivity to tuberculin among Japanese children suggested that exposure to environmental mycobacteria inhibits atopic sensitization through stimulation of type 1 immunity [31], as suggested by animal experimental models [32]. Humans have been always exposed to mycobacteria, mainly through natural soil dust and contaminated food. Rook and Stanford [11] proposed that mycobacteria might therefore have influenced the evolution of the immune system because they have been ubiquitous throughout mammalian phylogeny. Consequently, the concrete paving of modern cities and food hygiene may have deprived westernized populations of a fundamental stimulus for the maturation of their mucosa-associated lymphoid tissue, thus contributing to the asthma epidemic $[6,11,20]$. 


\section{Lipopolysaccharide}

Endotoxin from the cell wall of Gram-negative bacteria promotes survival and maturation of dendritic cells [33]. It is among the most potent stimuli for production of IL-12, a key molecule in type 1 immunity, by these cells [34]. Lipopolysaccharide from gut commensal flora may provide a major stimulus for postnatal maturation of dendritic cell function at both peripheral tissue sites and central lymphoid compartments [9]. Thus, deficient stimulation by Gram-negative bacteria in the gastrointestinal tract may result in deficient maturation of antigen-presenting cells and lower propensity to develop Th1 responses toward environmental antigens $[9,23]$. Inhalation of 'exogenous' endotoxin from house dust may protect against atopy [26], but it should be noted that Gram-negative bacteria that colonize the gastrointestinal tract are by far a greater 'endogenous' source of endotoxin. Interestingly, the gut microflora of infants growing in developing countries is characterized by early colonization, high turnover rate and high strain diversity of Gram-negative bacteria (ie Escherichia coli), suggesting a higher exposure to endogenous lipopolysaccharide as compared with infants reared in developed countries [24].

\section{Lactobacillus spp}

Allergic 2-year-old Swedish and Estonian children were colonized less often by lactobacilli, and harboured higher counts of aerobic bacteria (coliforms, Staphylococcus aureus) than did nonallergic children [21]. Lactobacilli from human gastrointestinal mucosa are strong stimulators of IL-12 production by mononuclear cells in vitro [35] and of major histocompatibility class II molecules in vivo [36]. The ingestion of fermented vegetables, which are rich in lactobacilli, has been associated with a lower risk of atopy and allergies in children exposed to an anthroposophic lifestyle [16]. Evidence that gut flora may affect the induction of oral tolerance has promoted calls for clinical trials aimed at establishing whether lactobacilli-containing preparations are useful in allergic diseases [37].

\section{Oral bacterial extracts}

Oral bacterial extracts have been claimed to stimulate immune responses against recurrent airway infections, but their therapeutic or preventive effect is far from proven [38]. Some allergists administer these preparations empirically as coadjuvants of oral allergen vaccines but, to our knowledge, scientific trials to evaluate this approach have not been performed.

\section{'Immunoeducation': a novel strategy or an utopian goal?}

Bacteria or bacterial products are already being tested against allergic diseases. Encouraging preliminary data are coming from animal studies in which DNA immunostimulatory sequences are used as adjuvants with allergen for allergen-specific immunotherapy, and from trials with
$M$ vaccae (SRL172) administered before the pollination period in patients affected by seasonal respiratory allergies [39]. These strategies are aimed at reducing allergic reactivity in patients and at treating or preventing sensitization to single specific allergens. Hopefully, they may therefore improve our potential for immunotherapy or immunoprophylaxis of sensitization toward some selected allergens [40]; however, we would continue to observe a high prevalence of atopic diseases among populations following a hygienic lifestyle, because it would be difficult to immunize against any potential environmental or food allergenic molecules.

Conversely, if we understood how microbes 'educate' our immune system we could perhaps learn to safely mimic their beneficial effect. Programmed 'immunoeducation' would consist of safe administration, by the correct route and at the correct dose and time schedule, of the variety of microbial stimuli that are required by the mucosal immune system during its development, and that are necessary to maintain an appropriate equilibrium between its components. This approach may be helpful in preventing atopy with a more 'physiological' stimulation, without the need of immunizing against all of the allergens that are potentially encountered during a whole lifetime.

\section{Conclusion}

Homeostasis of the immune system is so complex and microbial exposure is so diversified that, at the present state of our knowledge, 'immunoeducation' is far beyond our reach. More feasible and specific immunological therapies or prophylactic measures may emerge from the ongoing studies referred to above. Ultimately, although poor hygiene will never cure asthma, the hygiene hypothesis may result in new strategies in the fight against the allergy and asthma epidemic.

\section{Acknowledgements}

We are indebted to Jean Ann Gilder for revising and editing the text.

\section{References}

1. Woolcock AJ, Peat JK: Evidence for the increase of asthma worldwide. Ciba Found Symp 1997, 206:122-139.

2. Von Mutius E, Martinez FD, Fritzsch C, Nicolai T, Roell G, Thiemann $\mathrm{HH}$ : Prevalence of asthma and atopy in two areas of West and East Germany. Am J Respir Crit Care Med 1994, 149:358-364.

3. Strachan DP: Hay fever, hygiene and household size. $\mathrm{Br} M e d \mathrm{~J}$ 1989, 299:1259-1260.

4. Cookson WOCM, Moffatt MF: Asthma: an epidemic in the absence of infection. Science 1997, 275:41-42.

5. Martinez FD, Holt PG: Role of microbial burden in aetiology of allergy and asthma. Lancet 1999, 354:12-15.

6. Romagnani S: Regulation of the development of type 2 T-helper cells in allergy. Curr Opin Immunol 1994, 6:838-846.

7. Martinez FD: Role of viral infections in the inception of asthma and allergies during childhood: could they be protective? Thorax 1994, 49:1189-1191.

8. Strachan DP: Epidemiology of hay fever: towards a community diagnosis. Clin Exp Allergy 1995, 25:296-303.

9. Holt PG: Environmental factors and primary T-cell sensitisation to inhalant allergens in infancy: reappraisal of the role of infections and air pollution. Pediatr Allergy Immunol 1995, 6:1-10. 
10. Matricardi PM: Infections preventing atopy: facts and new questions. Allergy 1997, 52:879-882.

11. Rook GAW, Stanford JL: Give us this day our daily germs. Immunol Today 1998, 19:113-116.

12. Folkerts G, Busse WW, Nijkamp FP, Sorkness R, Gern JE: Virusinduced airway hyperresponsiveness and asthma. Am J Respir Crit Care Med 1998, 157:1708-1720.

13. Stein RT, Sherrill D, Morgan WJ, Holberg CJ, Halonen M, Taussig LM, Wright AL, Martinez FD: Respiratory syncytial virus in early life and risk of wheeze and allergy by age 13 years. Lancet 1999, 354:541-545.

14. Johnston SL, Bardin PG, Pattemore PK: Viruses as precipitants of asthma symptoms. III Rhinoviruses: molecular biology and prospects for future intervention. Clin Exp Allergy 1993, 23:237-246.

15. Platts-Mills TAE: Changes in the $20^{\text {th }}$ century environment: do they explain the increase in asthma? In Proceedings of the NIAID Symposium 'Asthma and Environment'. 1998 March 14; 54 ${ }^{\text {th }}$ AAAAl Annual Meeting, Washington. 1998:3-32.

16. Alm JS, Swartz J, Lilja G, Scheynius A, Pershagen G: Atopy in children with an anthroposophic lifestyle. Lancet 1999, 353:1485-1488.

17. Braun-Fahrlander C, Gassner M, Grize L, Neu U, Sennhauser FH, Varonier HS, Vuille JC, Wuthrich B: Prevalence of hay fever and allergic sensitization in farmer's children and their peers living in the same rural community. SCARPOL team. Swiss Study on Childhood Allergy and Respiratory Symptoms with Respect to Air Pollution. Clin Exp Allergy 1999, 29:28-34.

18. Strachan DP: Lifestyle and atopy. Lancet 1999, 353:1457-1458.

19. Matricardi PM, Rosmini F, Ferrigno L, Nisini R, Rapicetta M, Chionne P, Stroffolini T, Pasquini P, D'Amelio R: Cross sectional retrospective survey of the prevalence of atopy among Italian military students with antibodies against hepatitis A virus. $\mathrm{Br}$ Med J 1997, 314:999-1003.

20. Matricardi PM, Rosmini F, Riondino S, Fortini M, Ferrigno L, Rapicetta $\mathrm{M}$, Bonini S: Exposure to foodborne and orofecal microbes versus airborne viruses in relation to atopy and allergic asthma: epidemiological study. Br Med J 2000, 320:412-417.

21. Bjorksten $B$, Naaber $P$, Sepp $E$, Mikelsaar $M$ : The intestinal microflora in allergic Estonian and Swedish 2-year-old children. Clin Exp Allergy 1999, 29:342-346.

22. Matricardi PM, Bonini S: High bacterial turnover rate preventing atopy: a solution to inconsistencies impinging on the hygiene hypothesis? Clin Exp Allergy 2000, 30:1506-1510.

23. Wold AE: The hygiene hypothesis revised: is the rising frequency of allergy due to changes in the intestinal flora? Allergy 1998, 53:20-25.

24. Adlerberth I, Jalil F, Carlsson B, Mellander L, Hanson LA, Larsson P, Khalil K, Wold AE: High turnover rate of Escherichia coli phenotypes in the intestinal flora of infants in Pakistan. Epidemiol Infect 1998, 121:587-598.

25. Matricardi PM, Rosmini F, Rapicetta M, Gasbarrini G, Stroffolini T: Atopy, hygiene and anthroposophic lifestyle [letter]. Lancet 1999, 354:430.

26. Gereda JE, Leung DY, Thatayatikom A, Streib JE, Price MR, Klinnert $\mathrm{MD}$, Liu $\mathrm{AH}$ : Relation between house-dust endotoxin exposure, type $1 \mathrm{~T}$-cell development, and allergen sensitisation in infants at high risk of asthma. Lancet 2000, 355:1680-1683.

27. Holt PF, Sly PD, Bjorksten B: Atopic versus infectious diseases in childhood: a question of balance? Pediatr Allergy Immunol 1997, 8:53-58.

28. Roman M, Martin-Orozco E, Goodman JS, Nguyen MD, Sato $Y$, Ronaghy A, Kornbluth RS, Richman DD, Carson DA, Raz E: Immunostimulatory DNA sequences function as T helper-1-promoting adjuvants. Nature Med 1997, 3:849-854.

29. Kline JN, Waldschmidt TJ, Businga TR, Lemish JE, Weinstock JV, Thorne PS, Krieg AM: Modulation of airway inflammation by CpG oligodeoxynucleotides in a murine model of asthma. J Immunol 1998, 160:2555-2559.

30. Spiegelberg HL, Orozco EM, Roman M, Raz E: DNA immunization: a novel approach to allergen-specific immunotherapy. Allergy 1997, 52:964-970.

31. Shirakawa T, Enomoto T, Shimazu SI, Hopkin JM: The inverse association between tuberculin responses and atopic disorder. Science 1997, 275:77-79.

32. Erb KJ, Holloway JW, Soibeck A, Moll H, Le Gros G: Infection of mice with Mycobacterium bovis-Bacillus Calmette-Guerin (BCG) suppresses allergen-induced airway eosinophilia. J Exp Med 1998, 187:561-569.

33. Rescigno M, Granucci F, Citterio S, Foti M, Ricciardi-Castagnoli P: Coordinated events during bacteria induced maturation of dendritic cells. Immunol Today 1999, 20:200-203.

34. Le J, Lin JX, Henriksen-Destefano D, Vilcek J: Bacterial lipopolysaccharide-induced interferon-gamma production: roles of interleukin 1 and interleukin 2. J Immunol 1986, 136:4525-4530.

35. Hessle $\mathrm{C}$, Hanson LA, Wold AE: Lactobacilli from human gastrointestinal mucosa are strong stimulators of IL-12 production. Clin Exp Immunol 1999, 116:276-282.

36. Herias MV, Hessle C, Telemo E, Midtvedt T, Hanson LA, Wold AE: Immunomodulatory effects of Lactobacillus plantarum colonizing the intestine of gnotobiotic rats. Clin Exp Immunol 1999, 116:283-290.

37. Famularo G, De Simone C: Oral bacteriotherapy. Immunol Today 1998, 19:486-487.

38. Malling $\mathrm{HJ}$ : Bacterial vaccines: anything but placebo. Allergy 2000, 55:214-218.

39. Holgate ST: Science, medicine, and the future: allergic disorders. Br Med J 2000, 320:231-234.

40. Holt PG: Immunoprophylaxis of atopy: light at the end of the tunnel? Immunol Today 1994, 15:484-489.

Authors' affiliations: DASRS, RMAS, Laboratory of Immunology and Allergy, Pomezia (Rome), Italy (Paolo Maria Matricardi), and Institute of Experimental Medicine, CNR, Rome, Italy (Paolo Maria Matricardi and Sergio Bonini)

Correspondence: Paolo M Matricardi, MD, DASRS - RMAS, Lab di Immunologia ed Allergologia, Aeroporto Pratica di Mare, 00040 Pomezia (Rome), Italy. Tel: +39 336782 508; Fax: +39 067725 5269; e-mail: matricardi.pm@mclink.it 